\title{
The Development Strategy Analysis of Cross-Cultural Education in College English Translation Teaching
}

\author{
Li Meijing \\ Foreign Language Department \\ Jilin Business and Technology College \\ Changchun, China \\ 182076127@qq.com
}

\begin{abstract}
With the deepening of the world economic integration, the cross-cultural communication between countries becomes more and more frequent. The development trend of globalization puts forward higher requirements for college English teaching. At the same time, the cultivation of crosscultural translation ability has become the new focus of college English teaching. But for a long time, the college English classroom teaching focuses on students' listening, speaking, reading and writing skills and puts less emphasis on students' cross-cultural translation skills. This paper mainly introduces the present situation of college English translation teaching, points out the existing problems and proposes corresponding solution and strategies.
\end{abstract}

Keywords-college English teaching; English translation; cross-cultural translation teaching

\section{INTRODUCTION}

With the advent of the information age and the global economy, international cooperation and communication are rapidly promoted and multicultural "global village" is formed. English, as a global lingua franca, has become a tool to communicate with the outside world and an indispensable course to develop students' cross-cultural communicative competence in China. As an international language, one primary function of English is to enable speakers to share their ideas and culture with people coming from a variety of linguistic and cultural backgrounds. Thus, English learning should focus on improving learners' ability to understand cultures, including their own, and to use this understanding to communicate with people from other cultures successfully.

Cross-cultural education aims to improve students' crosscultural communicative competence, which is an important research project in cross-cultural communicative field. Many scholars have defined cross-cultural competence from different perspectives.
TABLE I. SCHOLARS` DEFINITION OF CROSS-CULTURAL COMPETENCE FROM DIFFERENT PERSPECTIVE ${ }^{[4]}$

\begin{tabular}{|l|l|}
\hline Scholars & Cross-cultural competence \\
\hline Chen and Starosta & $\begin{array}{l}\text { Cross-cultural competence is the ability to acknowledge, } \\
\text { respect, tolerate, and integrate cultural differences that } \\
\text { prepares one for global citizenship. They further propose } \\
\text { a sophisticated framework of cross-cultural competence, } \\
\text { which includes three interrelated components: cross- } \\
\text { cultural awareness, cross-cultural sensitivity, and cross- } \\
\text { cultural adroitness. }\end{array}$ \\
\hline $\begin{array}{l}\text { Spitzberg (1997), } \\
\text { Fantini (2006) }\end{array}$ & $\begin{array}{l}\text { Cross-cultural competence is comprised of knowledge, } \\
\text { skills, and motivation which are necessary to interact } \\
\text { effectively and appropriately with individuals from } \\
\text { different cultures. }\end{array}$ \\
\hline Deardorff (2004) & $\begin{array}{l}\text { Cross-cultural competence is the ability to interact } \\
\text { effectively and appropriately in intercultural situations. It } \\
\text { is supported by specific attitudes and affective features, } \\
\text { cross-cultural knowledge, skills and reflection. }\end{array}$ \\
\hline ECS(2011) & $\begin{array}{l}\text { Cross-cultural competence is the competence of } \\
\text { communicating effectively and appropriately on the } \\
\text { ground that the participants understand the cultural } \\
\text { context where communication happens, and respect the } \\
\text { cultural background of each other. }\end{array}$ \\
\hline Byram (1997) & $\begin{array}{l}\text { Cross-cultural competence is the knowledge, skills and } \\
\text { abilities to participate in activities where the target } \\
\text { language is the primary communicative code and in } \\
\text { situations where it is the common code for those with } \\
\text { different preferred languages. }\end{array}$ \\
\hline
\end{tabular}

The first three definitions of cross-cultural competence are from the perspective of sociology, psychology and communication science. However, cross-cultural competence proposed by ECS (2011) stressed the foreign language teaching field. English scholar Byram constructed an cross-cultural competence mode which combined the cross-cultural and foreign language teaching[1]. Therefore, it will be used as the theoretical principle in this research.

\section{THE IMPORTANCE OF CROSS-CULTURAL TEACHING IN COLLEGE ENGLISH TEACHING}

Because of the frequent economic, political and cultural exchanges between countries, college English learning is becoming more and more important. Especially after the implementation of quality education in China, people begin to 
realize that relying only on learning English itself is unable to meet the needs of communication. Culture is also an important part of language learning, so it has very important significance to implement cross-cultural teaching in college English teaching, which is mainly embodied in the following aspects:

\section{A. The Need of Improving the College Students' Language Learning Ability}

For college students, language learning ability is very important. Language teaching method is not only to tell students how to learn a particular language, but to cultivate students' ability of learning a language, enabling them to use language learning skills quickly in the language learning of university. For college English translation teaching, the implementation of cross-cultural teaching can improve students' language learning ability. This is because any language is based on a certain culture and has a profound cultural background to support it, so learning a language on the basis of the country's culture can improve language ability. On the other hand, it is necessary to be based on different occasions and communicate with specific characters when learning languages, which needs us to study language in different occasions under language background so as to avoid unnecessary cultural conflict.

\section{B. To Promote the Development of College Students' Social Demand}

Due to the development of current network technology, people can involve in basic social activities without going outside, such as shopping, communicating and learning, which causes some college students get separated from interpersonal society[2]. However, when college graduates entering society, it is an important and fundamental ability to carry on social communication which can affect a person's future development. In the process of cross-cultural communication, college students are supposed to communicate with other specific groups, like foreign friends, which can improve their ability to communicate with others and further strengthen their social communication skills. After graduation from college, college students with certain social communication skills are able to better fit into the society and make a certain contribution to the development of the society[3].

\section{The Demand of Developing Local Culture}

Language is a tool to communicate. In the process of communication, language is also a transmission of local cultural knowledge[5]. So, in common sense, cultural communication is a two-way process. China is a country with a splendid culture of five thousand years. If we need to involve ourselves into the big family of the world, we should show our own culture to other countries, therefore, we to the development and spread of Chinese culture. Therefore, it is necessary to carry on cross-cultural education in college English translation teaching, so as to understand foreign culture and spread local culture, letting the world have a better understanding of China.

\section{Comply with the Demand of Higher Education Internationalization Development}

For higher education, most students are from domestic areas, and there are also some foreign students studying in Chinese colleges for academic exchanges. So, internationalization development of higher education is an important tendency in the future. How to show respect each to the cultures of other countries and avoid cultural conflicts in daily life is determined by the cross-cultural education in college English translation teaching. Moreover, cross-cultural education in college English translation teaching can also help to improve the ability of college to further fuse into internationalization. From the current situation, domestic colleges, in addition to facing competition in domestic areas, also need to attract excellent students from the world, so as to continuously improve their strength and develop towards a higher and stronger direction.

\section{The Present Situation AND Problems of Cross- Cultural EDUCATION IN COLLEGE ENGLISH TRANSLATION TEACHING}

Through the above analysis and discussion, the crosscultural education in English translation teaching has very important significance, so we need offer certain support and encouragement for the actual English teaching in colleges. However, through the investigation and research, cross-cultural teaching in college English education still has certain problems and defects, which are mainly embodied in the following aspects:

\section{A. The Lack of Translation Teaching}

College English teaching puts little emphasis on translation teaching. In CET 4 and CET 6, translation also accounts for only a few points. It seems that translation teaching mainly exists to explain vocabulary and discourse in reading comprehension and only stays on the basic level[6]. Apparently, translation teaching has not been attached much attention at present, no speaking of the cross-cultural factors in translation teaching.

\section{B. Teachers in College Lack of Strong Consciousness of Intercultural Education}

Although the cross-cultural education plays a very important role in college English translation teaching, there are still some teachers lacking of strong consciousness of intercultural education, which is mainly embodied in the following aspects:

First, many English teachers believe that English translation simply involves the language skills of using words, grammar and sentence and is hardly connected to cultural exchange and communication. So in the daily teaching, the importance of cross-cultural education is not paid enough attention to, leading to the slow development of cross-cultural education in English translation teaching.

Second, teachers are incompetent to cross-cultural education. Most college English teachers graduated from domestic normal colleges and haven't really come into the 
contact with foreign culture in the process of learning, so, they are incompetent to cross-cultural teaching.

\section{The Students Cannot Adapt to the Foreign Culture}

Chinese and English are different in many aspects: cultural background, grammar and sentence structure, so students cannot adapt themselves to translation class, mainly manifested as follows: First, students in the university learn English only for the purpose of passing exam and obtain the corresponding certificate as the social groundwork for the future. So, in daily English study, students only focus on the appraisal content in English level test and fail to attach importance to the other content. Second, students affected by Chinese traditional culture can't adapt to the harmonious and interactive communication atmosphere in the classroom. They only aim to learn English knowledge associated to exam and seldom practice English in real life.

\section{The Teaching Content and Method of Cross-cultural Education Are Not Reasonable}

In some colleges, English translation teaching has begun to introduce cross-cultural education, but due to various objective restrictions and the imperfect cross-cultural education system, there still exist some unreasonable factors in the process of cross-cultural education in English translation teaching class, mainly embodied in the following aspects:

First, the content of cross-cultural education is unreasonable. At present, it has become an important content of quality education to improve the cultural quality of college students, but in the process of the cross-cultural education, there is a lack of systematic teaching content and teaching materials. Second, teaching methods are also unreasonable. Teachers often encourage students to learn about international culture by watching foreign movies, which is unable to effectively improve the teaching quality.

\section{E. Students' English Level Is Relatively Low}

The English level of students is mainly manifested in the mastery of English language as well as culture. Students' mastery of English language knowledge varies from individuals. This situation is particularly striking in general school. Many students, after the English learning in junior middle school and high school, still cannot do well in listening, speaking, reading and writing. Thus, English teaching in colleges has to remain in the aspect of improving students' ability in listening, speaking, reading and writing. As a matter of course, college English teaching is mainly concentrated on basic skills cultivation rather than cross-cultural teaching. In the aspect of culture, the level of students is generally low. Students seldom pay attention to extracurricular reading and fail to obtain cultural knowledge. Although the problem is reflected in the students, it at the same time highlights the problems existing in the teaching design.

\section{The DeVElopment StRategies OF THE CROSS-} CULTURAL EDUCATION IN COLLEGE TRANSLATION TEACHING

Through investigation and research, in the current college English translation teaching, the development situation of cross-cultural education is not optimistic, which seriously hinders college students' English cultural learning and is harmful to improving their learning ability at the same time, so we have to change the status quo of college English translation teaching from the following aspects:

\section{A. Understand the Importance of Cross-cultural Education}

As is known to all, cross-cultural education occupies very important position in English translation teaching. In order to further carry out cross-cultural education in English translation teaching, we first need to understand the importance of crosscultural education according to the following perspective: First, fully understanding the nature and significance of crosscultural education can help us recognize the importance of cross-cultural education and improve the teachers and students' recognition of the importance of cross-cultural education, so as to ensure the smooth progress of cross-cultural teaching; Second, colleges should also provide cross-cultural learning environment as well as relevant learning equipment, so as to create corresponding conditions for the cross-cultural education in English translation teaching.

\section{B. Improve the Teaching Quality of College Teachers Themselves}

Teachers play an important leading and guiding role in English teaching, so, in the process of intercultural education, college English teachers' quality can be improved from the following perspectives: First, help teachers set up the consciousness of the emphasis on cross-cultural teaching. English teachers not only need to value Chinese culture, but also need to bring foreign culture into local culture and guide students to set up the correct cultural consciousness and attitude towards the multi-culture; Second, increase the teachers' own quality because teachers' English teaching ability and application ability have an important influence on the improvement of students' English ability, so, in the crosscultural education in English translation teaching, it is necessary to improve English teachers' intercultural teaching ability. Third, attach importance to teachers' continuing education. English teachers also need to continually learn so that they can be competent to the work in English teaching.

\section{Scientifically Select Teaching Materials and Increase the Content of the Cross-cultural Education}

Scientific teaching material is one of the important conditions for cross-cultural education, so, in the cross-cultural education in English translation teaching, we need to scientifically select English teaching materials and increase the content of the cross-cultural education. Therefore, we need to do the following aspects: First, it is necessary to introduce the difference of cultures. Only in this way can we avoid the unnecessary cultural conflict in the practical process of teaching. Second, teaching material should focus on the real communication scene to correctly lead students to study. Third, enhance the contrast of culture, which can let the students attach importance to the learning of foreign culture on the basis of the in-depth study of native culture. 


\section{Improve Teaching Methods and the Teaching Effect of Cross-cultural Education}

Through the above analysis and discussion, in the current cross-cultural teaching process, the inappropriate teaching methods hinder the improvement of the teaching effect of cross-cultural education, so we need to make the following improvements: First, the introduction of the grouping teaching method lets the students involve into simple communication in groups and increases the fun of cross-cultural teaching. Second, give full play to the advantages of multimedia teaching method, and at the same time, use the Internet and other advanced teaching methods. Third, use whole language teaching method, letting students use facial expressions and body gestures in language communication.

\section{E. Pay Attention to Theoretical Study and Improve Students' Translation Skills}

There is almost no translation theory and skills in the teaching content of college English, so, it is difficult to meet the needs of modern society for the English translation ability of college students. It is thus necessary and appropriate to increase the content of translation theory and skills in college English translation teaching, letting the students have a preliminary understanding of translation course, so that the translation theory can guide students to improve their translation ability.

At the same time, we should choose suitable cross-cultural theory for non-English major students' learning. In the process of classroom teaching, college teachers can properly introduce some cross-cultural theories, such as uncertainty reduction theory, adaptation theory, culture construction theory and cultural conflict theory, etc. College English teacher, as the author thinks, can introduce these theories into classroom, teaching efficiently.

\section{CONCLUSION}

There is an inseparable relationship between culture and translation. Translation, as a kind of cross-cultural communication activity, must happen in a certain cultural environment. Translation teaching as an important part of college English teaching must pay much attention to the cultivation of cross-cultural translation ability. In the process of the cultivating college students' English practical ability, translation teaching has an important position and plays an important role. Therefore, it is of important significance to cultivate the students' cross-cultural English translation ability for the improvement of college students' English level and practical skills. College English teachers should introduce the cultivation of cross-cultural translation ability through the college English teaching process. Through the interpretation of cultural background knowledge, college English teachers can expand students' vision. Through the interpretation of translation theory and skills, college students' translation ability can be also improved and thus adapt to the requirements of the times.

\section{REFERENCES}

[1] Wang Hongzhi. Translation and Creation[M]. Beijing: Peking University Press, 2000

[2] Marilia Resende, Ji Yuhua. English Majors Teaching Material: Crosscultural Communication Practical Tutorial (Teachers' Book) (revised edition) [M]. Shanghai: Shanghai Foreign Language Education Press, 2012

[3] Nida, Eugene A. Language, Culture, and Translating[M].Shanghai: Shanghai Foreign Language Education Press, 1999

[4] Wu Guoquan. The developing strategy exploration of the cross-cultural education in college English translation teaching[J]. Journal of education teaching world, 2014 (23) : 236-238

[5] Webster Third New International Dictionary, Springfield, Massachusetts, U.S.A. Merriam-Webster Inc. Publishers.

[6] Don Snow.College English development course series: cross-cultural communication skills: how to deal with westerners (students' book) [M]. Shanghai: Shanghai foreign language education press, 2013. 